\title{
Lexis
}

Journal in English Lexicology

$7 \mid 2012$

Euphemism as a Word-Formation Process

\section{The Translatability of Euphemism and Dysphemism in Arabic-English Subtitling}

Mohammad Ahmad Thawabteh

\section{(2) OpenEdition}

Journals

Electronic version

URL: http://journals.openedition.org/lexis/385

DOI: 10.4000/lexis.385

ISSN: 1951-6215

\section{Publisher}

Université Jean Moulin - Lyon 3

Electronic reference

Mohammad Ahmad Thawabteh, "The Translatability of Euphemism and Dysphemism in ArabicEnglish Subtitling », Lexis [Online], 7 | 2012, Online since 25 June 2012, connection on 30 April 2019. URL : http://journals.openedition.org/lexis/385 ; DOI : 10.4000/lexis.385

\section{cc) (1) $(9)$}

Lexis is licensed under a Creative Commons Attribution-NonCommercial-NoDerivatives 4.0 International License. 


\title{
The Translatability of Euphemism and Dysphemism in Arabic-English Subtitling
}

Mohammad Ahmad Thawabteh ${ }^{1}$

\begin{abstract}
This paper explores the translatability of Arabic amelioration and pejoration in English subtitling, illustrated with a subtitled Egyptian film, Ramadan atop the Volcano by Arab Radio and Television (ART). The paper first examines the nature of euphemism and dysphemism. Both concepts are approached from the perspective of technical and translation paradigms. The study shows that the difficulties arising from translating euphemistic or dysphemistic-loaded utterances are numerous for being culture-specific on the one hand and for the technical dimension usually involved in subtitling on the other. The study shows that the subtitler may opt for one of three major translation strategies: (1) an omission of source language (SL) euphemistic or dysphemistic expressions in the target culture; (2) a retention of SL euphemistic or dysphemistic expressions by means of formal-based translation strategies; and (3) an addition of euphemistic or dysphemistic expressions in the target culture.
\end{abstract}

Keywords: euphemism - dysphemism - audiovisual translation - subtitling - strategies

1 Mohammad Ahmad Thawabteh is assistant professor of Translation and Interpreting at Al-Quds University, Occupied Palestinian Territories. 


\section{Introduction}

It goes without saying that language and culture are as inseparable as the two sides of a piece of a paper. Nostrand (as cited by Hammerly [1983: 516]) says that "language cannot be understood without reference to the culture of which it is a part and the social relation which it mediates." By the same token, Nida [1964: 147-163] argues that "translating can never be discussed apart from the cultures of respective languages, since languages are themselves a crucial part of culture."

Suffice to say that translation is a task fraught with many difficulties. Truly, there is a consensus among translation theorists and practitioners that these difficulties are attributed to the linguistic gap existing between the languages of translation, usually referred to as the Source Language (SL), the language from which translation activity takes place, and the Target Language (TL), the language to which translation occurs. Most of translation difficulties, however, are akin to cultural disparities or discrepancies between language pairs. In this vein, Gonzalez [2004: 1] points out that "the difficulty in decoding cultural signs can be more problematic for the translator than semantic or syntactic difficulties." Arabic and English stand as perfect examples of the languages belonging to two different cultures as Sofer [2002: 65-6] aptly remarks:

The conscientious Arabic translator is aware of the generic difficulties in working with two languages as different from each other as English and Arabic. [...], there are vast cultural differences between a Western language such as English and a Semitic language like Arabic. One cannot translate these languages without paying attention to these cultural differences.

Such differences between the two languages are expected to have a deleterious effect on the flow of communication in given interlingual exchanges. One of the linguistic phenomena which may pose difficulty in translation from Arabic into English is euphemism and dysphemism. Like other linguistic phenomena, such difficulty may be enormous in Audiovisual Translation (AVT), e.g. subtitling, dubbing, voiceover etc. This is due to the fact that "the difference between the skills required for subtitling and those required for translation [...] lies in the very technical aspects of subtitling" (Kruger [2008: 82]; see also Thawabteh [2011: 24] and Neves [2004: 135]). Kruger [ibid] further adds:

Subtitling requires all the skills that other modes require in terms of text analysis, subject expertise, language, awareness of context, quality control and so forth, but it also requires that the subtitler to be able to apply these skills within very rigid constraints of time and space, while adhering to specific conventions of quantity and form.

Translating euphemism and dysphemism is not only replete with myriads of linguistic and cultural problems, but it is also full of technical ones. The job of audiovisual translator is then viewed as challenging as Karamitroglou [2000: 104] describes: "the number of possible audiovisual translation problems is endless and a list that would account for each one of them can never be finite." It ensues, therefore, that "no one has ever come away from a foreign film admiring the translation, [inasmuch as] all of us have, at one time or another, left a movie theat[re] wanting to kill the translator" [Nornes 1999: 17]. 
In terms of translation as to audiovisual materials, different channels are pursued to observe maximum communicative import, namely (1) the verbal auditory channel, e.g. dialogue, background voices, and sometimes lyrics; (2) the non-verbal auditory channel, e.g. music, natural sound and sound effects; (3) the verbal visual channel, e.g. superimposed titles and written signs on the screen; and (4) the non-verbal visual channel, e.g. picture composition and flow [Baker 1998: 245]. According to Orero [2004: 86], "the content of the non-verbal channels has to be taken into account" To Orero [ibid.], "[a] screen adaptation of a 100, 000 word novel may keep only 20, 000 words for dialogue, leaving semantic load of the remaining 80,000 words [sic] the non-verbal semiotic channels - or to deletion."

The study falls within the ambit of AVT. Although euphemism and dysphemism have received attention in Arab Translation Studies [e.g. Farghal 1995a and 1995b and AlQadi 2009], no study has looked at them in relation to AVT, to the best of the researcher's knowledge. Therefore, the present study may be considered significant as it sheds new light on an AVT-related topic, namely euphemism and dysphemism, and in so doing, sets a path for further research in Arabic. Hopefully, this paper will increase the Arab subtitlers' awareness of euphemism and dysphemism as two linguistic phenomena against AVT.

In what follows we shall examine one of the most difficult problems in subtitling, namely translating Arabic euphemism and dysphemism into English, as is illustrated in a screen translation taken from Egyptian film Ramadan fawq il-burkān translated by ART Network into "Ramadan atop the Volcano". Fourteen euphemistic and dysphemistic expressions identified by the researcher as posing potential difficulties for the target audience are studies.

In the film, Ramadan, the action hero and an apparatchik, has barely scraped by on his own salary. He embezzled about half a million Egyptian Pounds because he knew very well that the lump sum that would be paid at retirement age in Egypt would be far less than the mount of money already embezzled. Ramadan was eloquent indeed, that he was able to understand legal language and use it efficiently, with all euphemistic and dysphemistic language use in mind.

\section{Euphemism and Dysphemism}

Various religious denominations, e.g., Christian, Hindu, Muslim or Judaic speak out against taboo language. In a particular exchange, there is a set of assumptions by the interlocutors that strike and guide a given conversation. The Collins Cobuild Advanced Learner's English Dictionary (2003) (henceforth CCALED) defines euphemism as "a polite word or expression that is used to refer to things which people may find upsetting or embarrassing to talk about, for example sex, the human body, or death." Allan and Burridge [1991: 14] offer this definition:

Euphemisms are alternatives to dispreferred expressions, and are used to avoid possible loss of face. The dispreferred expression may be taboo, fearsome, distasteful, or for some other reason have too many negative connotations to felicitously execute speaker's communicative intention on a given occasion.

In these two definitions, 'loss of face' is the reason beyond option for euphemism by interactants to achieve "understanding the speaker's intentions and subsequently the 
lexical correlates in his or her utterances" [Farghal 1995b: 366]. The definitions also raise the notion of felicity, i.e., 'appropriateness' or, as Farghal further explains, "the language user's option for a euphemism often emanates from contextual factors such as the social relationship between speaker and addressee or the level of formality induced by the setting" [ibid.]. Euphemism is then employed as an avoidance strategy with a view to ameliorate a situation (see Leech [2003: 53]). Yet scintillating conversation is observed.

Dysphemism, on the other hand, is defined by Concise Oxford English Dictionary [2004] as "a derogatory or unpleasant term used instead of a pleasant or neutral one." Dysphemism is thus the converse of euphemism. Whilst euphemism is used for amelioration, dysphemism is employed for pejorative expression. Sometimes "the context requires mentioning obscene expressions" [Al-Qadi 2009: 18]. In this case, "the native speakers' recourse is to use some euphemistic formulas to mitigate that horrible meaning" [ibid.]. Similarly, Al-Tha'albi [1972] claims that Arabic prefers equivocation to express obscene situations.

Like many other languages, English and Arabic are rich in euphemism and dysphemism. English employs several devices to euphemise and dysphemise [see Allan and Burridge 1991: 14]. Arabic, however, employs four major devices for euphemising, namely by means of figurative expressions, circumlocutions, remodelling and antonyms [Farghal 1995b: 368].

\section{Results and Discussion}

The theoretical framework established so far requires that we examine particular examples in order to diversify our argument. Let us indulge in a few illustrative examples to see how easy or difficult the subtitler's task is in pursuit of salient translation that would cater for SL euphemistic and dysphemistic expressions. For the sake of the study, taxonomy of the problems is presented.

\subsection{Figurative expressions}

A word or expression can be used in a figurative sense, i.e., departing away from its ordinary literal one (CCALED [2003]). This rhetorical device is part and parcel of human use of language. Insofar as euphemism is concerned, " $[t]$ he use of figures of speech is the most common device for euphemi[s]ing in natural language" [Farghal 1995b: 369]. In our data, we could spot the following figures of speech employed as devices for euphemism and dysphemism in Arabic, namely litotes, hyperboles, synecdoche, and metonymy.

\subsubsection{Litotes}

Litotes refer to ironical understatement in which an affirmative is expressed by the negative of its opposite, e.g. 'not bad' can be euphemised as 'good'. Consider the following example:

Example 1

SL: $\quad$ inta 'ultili ma tiftahshi bu'ak 


\section{TL: $\quad$ You told me not to open my mouth. (33 characters) ${ }^{2}$}

A close look at Example 1 shows that the SL euphemistic expression, i.e., ma tiftahshi bu'ak (lit. 'don't you dare open your mouth') is used by Ramadan with a view to concocting an excuse for any potential troubles in the cell. By means of utilising litotes, Ramadan wants to be less gratuitously offensive when speaking to the criminal master in the first encounter. Therefore, a formal strategy is employed bringing about an optimal translation whereby SL euphemism is translated into corresponding euphemism. Arguably, employing litotes may not go in harmony with the technical norms of subtitling as the inherent nature of litotes encourages displaying more words on the screen. For instance, the litotes 'You told me not to open my mouth' versus freelitotes 'You told me to shut up' is crystal-clear in terms of the number of characters. However, the subtitle in Example 1 above respects subtitling norms as to the number of characters (33 characters in total). For more illustration, consider Example 2 below:

Example 2:

SL: $\quad$ ma hadish biyakulha bi is-sahil

TL: $\quad$ How hard life is! (17 characters)

In Example 2 above, Ramadan expressed a strong statement by negating its opposite ' $m a$ hadish biyakulha bi is-sahil' (lit. 'What a hard way to earn a living!'). In the cell, Ramadan is suffering from other inmates' ill-treatment, to the point that he could not stand it anymore, thus opting for Arabic litotes to express that the amount of money he had embezzled and for which he is sentenced seven years imprisonment is worthy of anxiety and anguish. These shades of meaning seem to be lost in translation as Arabic euphemism is rendered into non-euphemistic expression in English.

\subsubsection{Hyperboles}

A rhetorical device employed by language users to say or write things that make something sound much more impressive than it really is, i.e., to exaggerate. Take Example 3 below:

Example 3:

SL: $\quad$ wi 'irift layh bi'ulu in is-sign ta'dīb wa tahdhīb wa islāh

TL: $\quad$ Now I know why imprisonment ${ }^{3}$ reforms people (24 characters)

In Example 3 above, Ramadan was cooped up in a cramped cell with other inmates. The fellow inmate was a master criminal who wanted all the inmates, including Ramadan, to be under his thumb. A terrible quarrel occurred in the cell in which the master criminal and Ramadan were in terrible and unbearable pain. Therefore, at the top of his voice, Ramadan employed a humanising metaphor, i.e., imprisonment is ta'dīb wa tahdhīb wa islah (lit. 'disciplinary', 'refinement' and 'reformatory') respectively in which "human qualities are applied to non-human objects" [Zaro 1996: 18]. The prison as a penal institution is usually euphemised as 'reformatory' or 'house of correction', the aim of which is to reform rather than to punish. Ramadan employs the figurative use of 'reforms' to ameliorate the situation as he was badly beaten by other inmates. He wants

\footnotetext{
2 In the present paper, the number of characters per subtitle is mentioned to show whether the technical aspect of subtitling is respected or not.

3 This subtitle segmentation is in the original.
} 
to stop it by hook or by crook so that he could escape the fellow's behaviour which is brutish and coarse, indeed. Technical-wise, the English subtitle respects subtitling limitations and constraints - the number of characters is 24. The subtitler opted for omission strategy whereby two of the three Arabic lexical items, namely tahdhïb (lit. 'discipline') and tahdhīb (lit. 'refinement') are left untranslated. Such a strategy is highly recommended in subtitling for it saves more space on the screen.

Very much related to technical constraints is also the notion of segmentation or linebreaks. The point at which the sentence in a subtitle is divided or broken up is known as the segmentation or line-break. "There are units in any sentence which must be kept together to help the flow of the text and the understanding of the content" [Karamitroglou 1998, Line-breaks]. Karamitroglou [ibid.] mentions the following units which must not be divided: (1) subject and verb; (2) verb and object; (3) article and noun; (4) adjective and noun; (5) preposition and the rest of a phrase; and (5) conjunction and the remainder of the sentence. Based on this argument, segmentation problems can be observed in Example 3 with 'imprisonment' and 'reforms'. Example 4 below is more illustrative:

Example 4:

SL: $\quad$ ana radi bi hukmi il biayh is-sukara

TL: $\quad$ I'll be content, whatever the ruling is. (40 characters)

In this example, the sukara metaphor (lit. 'suger' singular), is used by Ramadan to overstate the attributes of the judge to flatter him to have his verdict delivered as soon as possible. It is worth noting that the metaphor is a dehumanising metaphor which, according to Zaro [1996: 18], "non-human qualities, or objects, or creatures are applied to people and human qualities." However, the English subtitle lacks in the euphemism already exists in original Arabic, thus giving rise to a loss in subtle nuances of SL meanings. The English word 'sweet', metaphorically used to describe someone meaning pleasant, kind and gentle [CCALED 2003], can be added to the English subtitle as the spatial parameter allows for that (i.e., the number of characters is 40 ), something like the following two-line subtitle:

Sweet judge,

I'll be content, whatever the ruling is. (54 characters)

Example 5:

SL: $\quad$ yallah ya bayeh țusinī is-sab isnīn

TL: $\quad$ You can sentence me to 7 years. (31 characters)

In Example 5 above, Ramadan commits contempt of court as he insists that he is adjudged to be guilty, no more. To this end, he uses a dysphemistic item - tusini (lit. 'thrashing'). Such hyperbolic language is contextual-bound [see Al-Qadi 2009]. Nevertheless, the English subtitle is neutral, and it falls short of original Arabic.

\subsubsection{Synecdoche}

Synecdoche is a figure of speech utilised in intercultural communication to euphemise or dysphemise. Definitionally, a part is made to represent a whole or vice versa. Synecdoche is sometimes culture-specific. For example, 'spend a penny' is a known British urinary euphemism, usually used instead of 'go to the lavatory'. To express the 
same euphemism in Arabic, some Arab countries, e.g., Jordan, Palestine etc. use bidi arūh 'ala is-safarah (lit. 'I want to go to the embassy'). To elaborate on this, we should examine the following example:

Example 6:

$$
\begin{aligned}
& \text { SL: - 'albi ma'mākeya 'ustādh Ramadan. } \\
& \text { - khali 'albak 'ala rūhak } \\
& \text { TL: - My heart aches for you } \\
& \text { - Look after yourself. ( } 26 \text { characters) }
\end{aligned}
$$

In this example, after guilty verdict was delivered, Bashbishi, Ramdan's workmate, sadly uttered 'albi ma'māk ya (lit. 'my heart is with you'). This is an Arabic euphemism in which the part of the body, that is, 'the heart' is made to represent the whole, i.e., the speaker per se. This euphemism is used to express how sad or depressed someone is, especially when they suffer but they can do nothing to help others. As Example 6 above shows, the subtitler opts for more or less a bland translation for he/she does not cater for the pragmatic force the SL has shown. Thus the SL euphemism is rendered into TL dysphemism.

\subsubsection{Metonymy}

Metonymy is a figure of speech in which a word or expression is used as a substitute for something or someone with which it is closely associated. Such association may be casual as Example 7 below shows in which 'overreaction' is associated with Yousif Wahbi, an Egyptian stage and film of the 1930s and 1940s whereas 'unfailing cheerfulness' is apropos of Isma'îl Yasīn, an Egyptian comedian actor.

Example 7:

SL: ih il-kalam dah inti 'at'amlīlī fiyha Yousif Wahbi ana 'aiz kalam Isma'îl Yasīn bi șaraḥah

TL: Stop overreacting and be cheerful for a change! (50 characters)

As can be seen in Example 7 above, the subtitler opts for the attributes associated with Yousif Wahbi and Isma'īl Yasīn, namely 'overreaction' and 'unfailing cheerfulness' respectively. The subtitler entirely omitted the proper names, perhaps because of culture-specificity of the proper names in question and/or the spatial constraints akin to subtitling. In the SL, Ramadan attempts to ease the degree of intensity insofar his fiancée is concerned, thus opted for the proper names euphemisms. Strategy-wise, the Arabic euphemistic expressions are rendered into neutral lexical items which is, technically, seem to be an option, for they save more characters on the screen (e.g. only 50 characters per two-line subtitle), and probably facilitate reading by TL viewers. Nevertheless, segmentation problem is clear in Example 7 above in which break-up is wrongly done between 'be' and 'cheerful'.

Several subtitling theorists have posited that the translator should make comprehension easier for the audience by "using simple and unambiguous language and syntax with careful punctuation" [Hurt and Widler as cited in Karamitroglou 1998]. As shown from the examples above, the complexities of euphemisms or dysphemisms are numerous, e.g. figurative language, metonymy, circumlocution, long phrases (leaving little space on the screen, among), many others. 


\section{Remodellings}

Farghal [1995b: 375] points that remodelings are "another device for euphemi[s]ing in colloquial rather than standard Arabic. They involve the substitution of a semantically unrelated or a nonsensical word for an offensive or a dispreferred one." This process is phonological and sometimes (but not neccesarliy) gives rise to semantic distortion, e.g., jadhaba remodels jabadha and still preserves the same semantic load, i.e., 'change the course of action'. Contrary to Farghal's argument, standard Arabic uses remodelings as a rhetorical device to euphemise. Al-Tha'albi [1972:371] argues that al-Qalb (Remodellings) is typical of Arabs use of the language, e.g., bakala (lit 'to mix flour with date jam') versus labaka (lit. 'to become confused'). Examples of how standard Arabic employs euphemistic words by means of remodelling the offensive words are "asala versus gasla and fahaja verus faxaja, amonga many others. These are euphemisers for having sexual intercourse with someone. For sake of illustration, consider Example 8 below:

Example 8:

SL: wa 'adabūh!

TL: $\quad$ Fix him. (8 characters)

The master criminal gave orders for other prisoners: wa 'adabūh (lit. 'take care of him'), a euphemism that is used with fixing one's hair, clothes or make up to look more neat and tidy. This euphemism is employed by the text producer instead of 'idribūh (lit. 'beating him up'). As can be shown in Example 8 above, a semantically unrelated word, i.e., $w a$ 'adabūh remodels the common offensive word 'idribūh. It is worth noting that this choice of substitute goes beyond the usual remodelling, e.g. 'What the hell is that?' versus 'What the heck is that?. Both are used to emphasise a question, but only the latter is less rude than the former. Remodelling seems to be pragmatically-motivated. This is clear in Example 8 above in which the choice of substitute has more pragmatic load, that gentle manner and honeyed tones employed by the master criminal aim to reassure Ramadan that everything in the cell was fine. The subtitle seems to be a successful rendition. In the final analysis, Ramadan appeared self-assured as Example 9 below shows:

Example 9:

SL: $\quad$ - ma tīji tukil ma'i.

- țab bas i-ywaḍabūni. yallah ya jama'ah waḍabūni 'ashan 'awiz 'akul lu'ma ma'ir-ragil

TL: $\quad$ - Have a bite with me.

- I'll get fixed then I'll come right away (41 characters)

Please, everyone, fix me up.

I want to have a bite? (54 characters)

In Example 9 above, a prisoner is eating and invites Ramadan to a meal. Because he could not read the master criminal's mind well, he kindly refused the invitation for the time being uttering tab bas iywadabūni (lit. 'until I am taken care of'). Ramadan opts out of an offensive word in favor of a remodeling. Technically, it seems that all the subtitles in Example 9 observe the subtitling norms. 


\section{Omissions}

This is a strategy used for euphemising in English whereby words thought to be rude are omitted. This can be by means of (1) quasi- omission suspension dots (...), dashes $(---)$, asterisks $\left({ }^{* *}\right)$ and inarticulated sounds, e.g., $\mathrm{mm}$, er, etc.; and (2) full-omissions [Zaro 1996]. To elaborate on this, we should examine the following example:

Example 10:

SL: $\quad y \bar{a}$ sa'āādit il bayh ana law kunti 'ayiz 'aqūl 'an makan il-fülūs kān lāzmitha il-lamah dī di 'a'da mitkalifa

TL: 'Sir, if I wanted to tell where the money was, I would have done so a long time ago' (85 characters)

For the sake of synchronisation, the SL utterance is rendered into two main subtitles, each of which includes a two-line subtitle, thus going in harmony with subtitling norms. However, the subtitle register a segmentation error, namely with 'a long' and 'time ago' which translate kān lāzmitha il-lamah dī (lit. 'why then is a court of law for'). In the court room, Ramadan did his best that the judgment be made without further ado. He confessed to emezzelment and knew very well that he will be imprisoned for seven years in line with Egyptian criminal law. All what il-lamah (lit. 'a court of law') should do is that Ramadan is convicted of the crime in question and that there is no need to call upon witness to appear in a court of law. The euphemistic form il-lamah shows rhetoric in which he does his best to convince and impress the judge, and so does the form mitkalifa (lit. 'costly'). However, Example 10 observes full omissions of two euphemistic terms, that is, il-lamah and mitkalifa. Hence, the SL euphemism is translated into free TL euphemism.

Subtitle-wise, omission strategy used to euphemise may be insufficient. Punctuation should be meticulously dealt with. Karamitroglou (1998, Punctuation and letter case) argues:

Sequence dots or ending triple dots should be used right after the last character of a subtitle (no space character inserted), when the subtitled sentence is not finished on one subtitle and has to continue over the consecutive subtitle. The three "sequence dots" indicate that the subtitled sentence is incomplete, so that the eye and the brain of the viewers can expect the appearance of a new flash to follow.

It may be confusing for the target audience, therefore, to recognise whether the sequence dots used in a subtitle tend to euphemise or to indicate subtitled sentence is incomplete. Take Example 11:

SL: $\quad$ ana ma'indish muhafiz fi is-sgin

TL: $\quad$ There is no governor in here, you... (35 characters)

Ramadan fell victim to the prison bully-boy who started to cuss and shout in the cell. Instead of using explicit ' son of a bitch', bully-boy ameliorated the situation by means of omission strategy, e.g., 'you...'. 


\section{Circumlocutions}

A common device for euphemising in Arabic is circumlocutions (Farghal [1995b]). Circumlocutions "involve the breaking down of neutral or taboo terms to their atomic concepts [..., thus mitigating the force of the unfavourable or bad connotations of the terms in question" (Farghal [1995b: 372]). Circumlocution is then a politeness strategy that is meant to express something in more words than required. Example 12 below illustrates the point:

Example12:

SL: $\quad$ ya siadit ir-rayis il-qa'adah il-qanūnyyah bit'ūl 'ana ili 'atkalim wi hw ail yuskut il-'adyyah 'adyyiti wi guha awla bilahmi thurah

TL: $\quad$ Your honor, I should have the Right to speak simply Because this is my case. (31 characters)

The Arabic proverb wi guha awla bi lahmi thurah (lit 'Juha" is more entitled to eat his bull's meat than others are') is functionally equivalent to English 'you make your bed so you must lie on it'. As can be noted in Example 12, Ramadan uses an excessive number of words to state something that can be expressed in a few words. The Arabic euphemism proverb shows indirectness on the part of Ramadan because he meticulously chooses his words no matter how many they are to convince the judge of his stance. The subtitle is condensed and seems to have conveyed the message.

Example 13:

SL: $\quad$ as-saāmu 'alaykum yā mugrimīn yā 'awbāš yā zbālit il-mugtama'

TL: 'Hello, you low criminals! You, scum of society!' (47 characters)

The prison guard pushed Ramadan in the prison, greeting the prison's inmates with a low-variety language reflecting the status of scumbags inside the prison. As can be noted in Example 13 above, the original Arabic uses several words to express the idea that the prisoners are too bad, namely mugriminn (lit. 'criminal'),'awbāš (lit. 'riffraffs') and zbālit il-mugtama' (lit. 'scum').

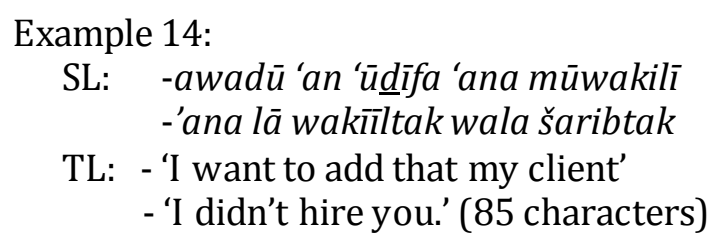

The Arabic euphemism 'ana lā wakīltak wala šaribtak (lit. 'neither did I offer you a meal, nor did I provide you with a drink') in Example 14 above merits close investigation. The onset of the court session witnessed disagreement between Ramadan and his defence lawyer who was hired by a court of law. Ramadan beat the lawyer at his game by means of alliteration of two words, i.e., mūwakilì (lit. 'my client') and wakīltak (lit. 'to feed you'). With such decorum and respect, Ramadan uses the euphemism in question to persuade the defence lawyer not to take the case as Ramadan insists on carrying out his

\footnotetext{
${ }^{4}$ Juha is an old comic around whom countless fair tales were written.
} 
own defence. Obviously, the Arabic euphemistic phrase is rendered into TL freeeuphemistic one.

\section{Conclusion}

The foregoing analysis has shown that subtitling euphemistic or dysphemistic problems can be not only linguistic, cultural, but they can also be technical. Therefore, the task of the subtitler is challenging and demanding. Due attention should be paid to technical dimension so that number of characters, synchronisation, segmentation problems, among others, can be reduced to a minimum.

The study shows that three major strategies are opted for (1) SL euphemistic or dysphemistic expressions are rendered into TL free of euphemistic or dysphemistic expressions; (2) SL euphemistic or dysphemistic expressions are translated into TL euphemistic or dysphemistic expressions; and (3) SL free of euphemistic or dysphemistic expressions are transferred into TL euphemistic or dysphemistic expressions. These strategies should be carefully employed in relation to a multisemiotic blend of many different channels usually integrated in audiovisual materials, e.g., verbal auditory channel, the non-verbal auditory channel, etc. In Example 8 above, the film sequence shows that a set of actions, e.g., that Ramadan is in inmates' clutches and that he spars with them, etc. seems to be irrelevant with the lexical realisation on the screen, namely the use of wa 'adabūh! In the sequence, no one fixes Ramadan's hair or clothes. It is then non-verbal auditory channel and non-verbal visual channel which contribute to observe very euphemistic use of wa 'aḍabūh.

Technically speaking, the translation of a SL euphemism into a TL counterpart poses technical difficulties because a kind of amplification is observed as is the case with litotes and circumlocutionary euphemisms whereby more words are usually displayed on the screen. Example 1 above is a case in point. As for circumlocution, shown in Example 12 above, the subtitler opted for ideational equivalence, i.e., Arabic circumlocutionary euphemism is rendered ideationally into English and thus falls within the allowable spatial dimension subtitling demands.

\section{Bibliography}

Allan Keith \& BuRRIDGE Kate, Euphemism and Dysphemism: Language Used as Shield and Weapon, New York: Oxford University Press, 1991.

AL-QADI Nasser, "A Sociolinguistic Comparison of Euphemisms in English and Arabic", Journal of King Saud University, Vol. 21, 2009: 13-22.

AL-TH'ALBI Abu Mansour, Fiqih al-Lughah wa Sir al-'Aarabyiah. Edited and explained by Mustafa Al-Saqa, Ibrahim Al-Abyari and Abd il-Hafeez Shalabi, eds. Cairo, Mustafa il-Babi il-Halabi, 1972.

BAKER Mona, Routledge Encyclopaedia of Translation Studies, London, Routledge, 1998.

Collins Cobuild Advanced Learner's English Dictionary, The University of Birmingham, HarperCollins Publishers, 2003.

Concise Oxford English Dictionary, 11 th ed. Oxford: Oxford University Press, 2004.

FARGHAL Muhammad, "The Pragmatics of 'inšāllah in Jordanian Arabic", Multilingua, Vol. 4, 1995a: 253-270.

FARGHAL Muhammad, "Euphemism in Arabic: A Gricean Interpretation", Anthropolgical Linguistics Vol. 37, 1995b: 336-378 
GonzaLEz Belén,"Translating Cultural Intertextuality in Children's Literature”, Available from: http://www.velkho.wenk.be/conferenc.clt/gonz\%e11ez.htm [Accessed May 2011], 2004.

Hammerly Hector, Synthesis in Second Language Teaching: An Introduction to Linguistics, Washington, Second Language Publication, 1983.

Karamitroglou Fotios. "A Proposed Set of Subtitling Standards for Europe". In Translation Journal, Available from: http://accurapid.com/journal/04stndrd.htm [Accessed April 2011], 1998.

KARAMITROGLOU Fotios, Towards A Methodology for the Investigation of Norms in Audiovisual Translation: The Choice Between Subtitling and Revoicing in Greece, Rodopi, 2000.

KRUGER Jan-Louis, "Subtitling training as part of a general training programme in the language professions", in DIAZ CINTAS Jorge (Ed.), The didactics of audiovisual translation, Amsterdam, John Benjamins, 2008, 71-87.

LEECH Geoffrey, Semantics, England: Penguin Books Ltd, 1974.

Neves Josélia, "Languages Awareness through Training in Subtitling", in OERERo Pilar (Ed.), Topics in audiovisual translation, John Benjamins Publishing Company 2004, 127-141.

NiDA Eugene, Towards the Science of Translation, Leiden, E.J. Brill, 1964.

NoRNES Abé Mark, "For an Abusive Subtitling”, Film Quarterly, Vol. 52 1999: 17-34.

Orero Pilar, Topics in Audiovisual Translation, John Benjamins Publishing Company, 2004.

SOFER Morry, The translator's Handbook, Rockville \& Maryland, Schreiber Publishing, 2002.

ThAwaвTEн Mohammad, "Linguistic, cultural and Technical Problems in English-Arabic subtitling", SKASE Journal of Translation and Interpretation, Vol. 5, 2011: 24-44.

Zaro Naji, A Pragmaphemistic Aspect in English-Arabic Translation: A Problem in Equivalence, Unpublished MA Thesis, Irbid: Yarmouk University, 1996. 